\title{
Dyeing and fastness properties of Quercus robur with natural mordants on natural fibre
}

\author{
Syed Maqbool Geelani ${ }^{1 *}$, Shoukat Ara ${ }^{1}$, Naseer A Mir ${ }^{2}$, S. J. A. Bhat ${ }^{2}$ and P. K. Mishra ${ }^{3}$
}

\begin{abstract}
Dyeing potential of a natural dye extracted from Quercus robur L. (fruit cups) with a combination of Salix alba L. and Populus deltoides Bartram ex marsh (wood ash) mordants was studied on wool, cotton, silk and pashmina fabrics. Experiment was carried out in different combinations including and excluding mordants by adopting different mordanting methods. Dyeing performance was assessed in terms of dye absorption (\%), Colour values (CIELAB), Colour strength $(K / S)$, and fastness properties. The dye in combination with mordants showed significant importance and resulted in different shades on wool, silk and pashmina fabrics. However, the cotton fabric did not show much affinity for the dye and mordant and showed less affinity for the dye and mordants with lower values of colour quality and retention grades. Fastness properties of all dyed fabrics recorded excellent grades with slightly lower grades in unmordanted dyed samples.
\end{abstract}

Keywords: Dyeing, Quercus robur, Salix alba, Populus deltoides, Textiles, Pollution

\section{Background}

The usage of the synthetic dyes in textile dyeing industries is increasing due to cheaper and wider ranges of brighter shades in comparison to natural dyes. Coloured products have gained lot of importance in present day societies. Textile dyes are considered as the most polluting industrial process. Increase in the demand of the dyed textile products with proportional increase in its manufacturing by utilizing synthetic dyes has contributed to the severe pollution of water, soil and as a whole to our environment (Dos et al. 2007). The effluent containing heavy load of harmful chemicals of the textile industries is one of the major polluters of our environment (Gyanendra et al. 2015) Excessive use of the synthetic dyes in textiles has led serious health hazards and disturbances in eco-balance of nature. Estimated consumption of the textiles globally is around 30 million tonnes for which the expected increase is at the rate of about $3 \%$ per annum (Rajendran and Thamarai 2014). About 700,000 tonnes of different dyes are

\footnotetext{
* Correspondence: geelani111@gmail.com

${ }^{1}$ Environmental Sciences, SKUAST-K, Shalimar, Srinagar, Jammu and Kashmir, India

Full list of author information is available at the end of the article
}

required for the colouration of such a bulk quantity of the textiles (Rungruangkitkrai and Mongkholrattanasit 2012). The global production of the synthetic dyes is over $7 \times 10^{5}$ annually (Ogugbue and Sawidis 2011). The adverse of the synthetic dyes can be prevented by utilizing eco-friendly dyes and methods (Wanyama et al. 2014). Natural dyes exhibit long endurance, beauty and charm and can be of varied sources like mineral, insect animal and plant of which roots, flowers, barks, leaves, fruits and stems can be used. The international rising demand of the natural dyes is about 10,000 tonnes which is mere $1 \%$ of the world synthetic dye consumption (Sachan and Kapoor 2007). It is of relevance to optimize the colouring process with the objective of reducing the environmental impact of the textile dye industry. The associated toxicity, carcinogenicity and allergic reactions of the synthetic dyes has raised an interest in the revival of the natural dyes which are clinically safer, disease free, non-polluting and biodegradable (Kulkari et al. 2011; Aminoddin 2010, 2010). Nonsubstantivity of the natural fibre towards natural dye requires a mordant which are usually derived from metallic salts like alum, chrome, copper sulphate, stannous chloride and ferrous sulphate which does not make the 


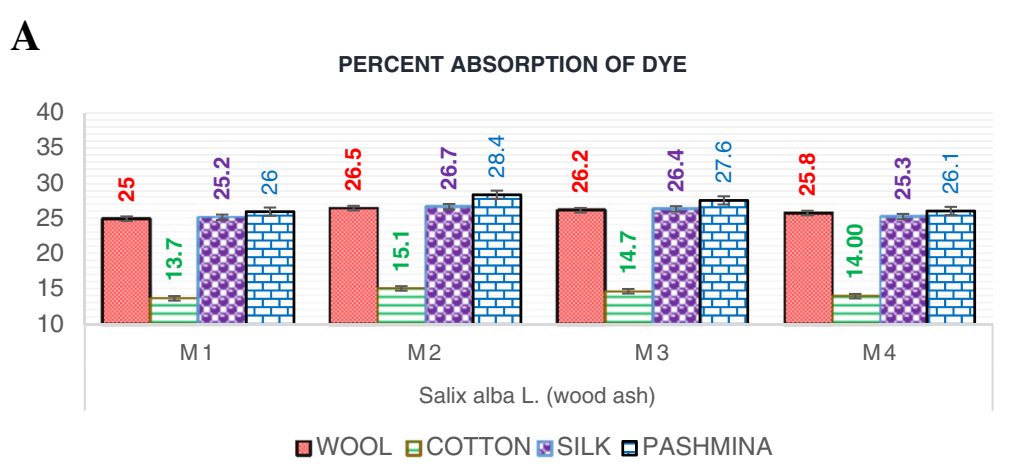

M1: Without Mordant, M2: Pre Mordanting, M3: Simultaneous Mordanting, M4: Post Mordanting

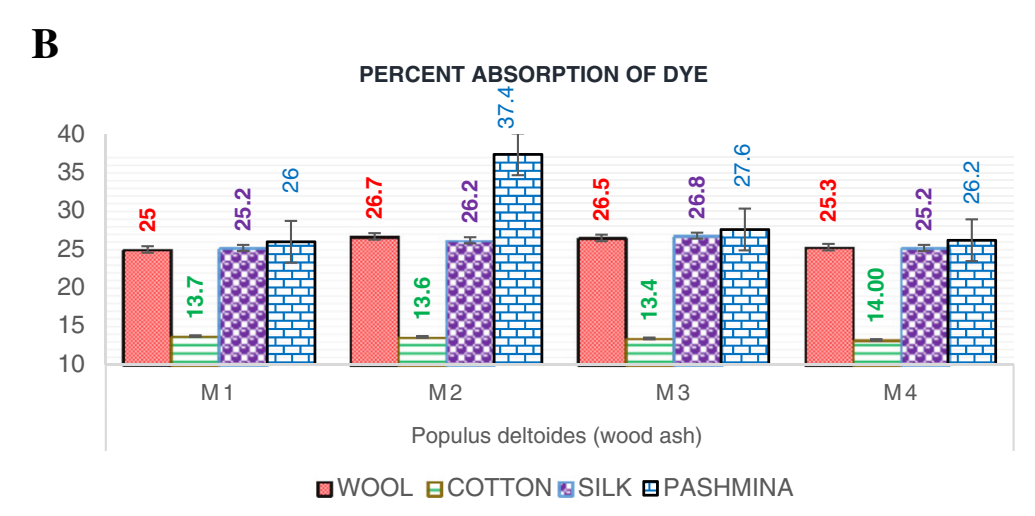

M1: Without Mordant, M2: Pre Mordanting, M3: Simultaneous Mordanting, M4: Post Mordanting

Fig. 1 a Percent absorption of the dye with Salix alba L. (wood ash). M1: without mordant, M2: pre-mordanting, M3: simultaneous mordanting, M4: post-mordanting. b Percent absorption of the dye with Populus deltoides (wood ash). M1: without mordant, M2: pre-mordanting, M3: simultaneous mordanting, M4: post-mordanting

process of the dyeing fully eco-friendly (Lodrick et al. 2015). The increased awareness on hazardous, toxic and allergic reactions associated with synthetic dyes has raised a growing demand for the natural dyes and dyed products (Singh and Srivastava 2015). The rising demand of the dyed products and consciousness about the human health and pollution has marked a need for the revival and usage of the natural dyes and dyed products all over the world. Kashmir valley abounds a rich and varied biodiversity of plants which needs to get explored and utilized commercially as a varied sources of the dyes and mordants. India is one of the 17 megadiverse countries having a rich biodiversity and wide range of natural products (Singh and Srivastava 2015). A sustainable linkage must be developed between cultivation, collection and use of the natural dye sources in our country which has a rich biodiversity and plenty of raw materials (Kumaresan et al. 2011). Kashmir valley enriches with natural dye sources, which has to be explored. The dyeing potential of the similar species using different mordant is only reported by Geelani et al. (2015a, b). The work was conducted to explore the dyeing potential of Quercus robur, Salix alba and Populus deltoides for their usage in textile industries in order to reduce the pollution of the synthetic dyes. The aim of the work was to extract the natural sources of the textile dyes and mordants by adopting eco-friendly practices. The specific objectives were to compare the efficiency of the dye with the suitable mordant on the fabrics in producing different shades and hues, analysing the colour values and assessment of the colour fastness properties of the dyed fabrics.

\section{Methods}

\section{Collection of material}

The dyeing material of Quercus robur L. (fruit cups) was collected from Dachigam wild life sanctuary, Srinagar, and mordant materials Salix alba L. (wood) and Populus deltoides Bartram ex Marsh. (wood) were collected from university outskirts at Srinagar city (Plate 1). Wool and cotton were purchased from Government Silk Weaving Factory and Poshish (JKHDC) outlet at Srinagar (J\&K). 
Table 1 Average colour coordinates of different fabrics treated with Quercus robur L. (fruit cups) dye using Salix alba L. (wood ash) as mordant

\begin{tabular}{lllllll}
\hline Methods & \multicolumn{7}{c}{ Colour coordinates } \\
\cline { 2 - 7 } & $L^{*}$ & $a^{*}$ & $b^{*}$ & $C^{*}$ & $h^{\circ}$ & $\Delta E$ \\
\hline Wool fabric & & & & & & \\
Without mordant & 73.0 & 4.3 & 31.2 & 31.5 & 82.0 & 31.1 \\
Pre-mordanting & 68.2 & 3.4 & 28.6 & 28.8 & 83.1 & 24.7 \\
Simultaneous mordanting & 64.5 & 4.5 & 27.4 & 27.7 & 80.5 & 27.0 \\
Post-mordanting & 61.8 & 6.0 & 28.9 & 29.5 & 78.2 & 30.3 \\
Cotton fabric & & & & & & \\
Without mordant & 80.4 & 4.5 & 19.7 & 20.2 & 77.0 & 18.1 \\
$\quad$ Pre-mordanting & 84.6 & 3.0 & 16.1 & 16.4 & 79.0 & 12.6 \\
Simultaneous mordanting & 79.5 & 3.8 & 17.9 & 18.3 & 77.8 & 26.2 \\
Post-mordanting & 80.4 & 3.7 & 18.8 & 19.2 & 78.9 & 17.5 \\
Silk fabric & & & & & & \\
Without mordant & 65.8 & 4.8 & 28.9 & 29.3 & 80.5 & 30.0 \\
Pre-mordanting & 68.0 & 7.4 & 25.6 & 26.7 & 73.8 & 26.2 \\
Simultaneous mordanting & 60.7 & 4.8 & 24.6 & 25.0 & 78.8 & 31.2 \\
Post-mordanting & 61.7 & 5.8 & 18.8 & 19.6 & 73.5 & 28.1 \\
Pashmina fabric & & & & & & \\
Without mordant & 55.7 & 4.3 & 25.5 & 25.9 & 80.3 & 26.9 \\
Pre-mordanting & 60.4 & 7.2 & 29.4 & 30.2 & 76.2 & 24.9 \\
Simultaneous mordanting & 55.5 & 4.4 & 22.3 & 22.8 & 78.8 & 26.2 \\
Post-mordanting & 47.9 & 3.2 & 23.7 & 23.9 & 82.3 & 33.7 \\
\hline
\end{tabular}

Silk was procured from J\&K Govt. Silk Weaving Factory at Rajbagh, Srinagar, and pashmina fabric was purchased from FS Shawls, Srinagar.

\section{Preparation of dyeing material}

The shade dried fruit cups of Quercus robur L. were washed with distilled water and dried in a tray drier at $80{ }^{\circ} \mathrm{C}$ for $2 \mathrm{~h}$. The material was finely powdered with the help of a grinding machine and passed through a standard test sieve (BSS-14). The resultant material was then used as dye material.

\section{Preparation of mordant}

The wood of Salix alba and Populus deltoides was burn completely into ash and soaked in distilled water for 15 days. The resultant solution was filtered and kept under refrigeration for future usage.

\section{Extraction of dye}

For complete extraction of the dye in aqueous solution, soxhlet apparatus was used. One litre of distilled water was used for $100 \mathrm{~g}$ of the plant material. The material was kept for reflux for about $8 \mathrm{~h}$ at $80-85{ }^{\circ} \mathrm{C}$. The extracted material was evaporated at $65{ }^{\circ} \mathrm{C}$ using rotary
Table 2 Average colour coordinate values of different fabrics treated with Quercus robur L. (fruit cups) dye using Populus deltoides Bartram ex Marsh (wood ash) as mordant

\begin{tabular}{lllllll}
\hline Methods & \multicolumn{7}{c}{ Colour coordinates } \\
\cline { 2 - 7 } & $L^{*}$ & $a^{*}$ & $b^{*}$ & $C^{*}$ & $h^{\circ}$ & $\Delta E$ \\
\hline Wool fabric & & & & & & \\
Without mordant & 73.0 & 4.3 & 31.2 & 31.5 & 82.0 & 31.1 \\
Pre-mordanting & 56.8 & 5.2 & 25.3 & 25.9 & 78.3 & 32.9 \\
Simultaneous mordanting & 56.2 & 3.3 & 16.4 & 16.7 & 78.6 & 30.9 \\
Post-mordanting & 61.0 & 7.0 & 21.7 & 22.8 & 72.0 & 28.1 \\
Cotton fabric & & & & & & \\
Without mordant & 80.4 & 4.5 & 19.7 & 20.2 & 77.1 & 18.1 \\
Pre-mordanting & 81.7 & 3.0 & 14.0 & 14.3 & 77.8 & 13.5 \\
Simultaneous mordanting & 88.6 & 3.1 & 25.8 & 26.0 & 83.2 & 19.3 \\
Post-mordanting & 91.1 & 2.7 & 10.3 & 10.7 & 74.9 & 3.9 \\
Silk fabric & & & & & & \\
Without mordant & 65.8 & 4.8 & 28.9 & 29.3 & 80.5 & 30.0 \\
Pre-mordanting & 66.2 & 6.5 & 25.7 & 26.5 & 75.7 & 27.4 \\
Simultaneous mordanting & 60.6 & 4.1 & 20.3 & 20.7 & 78.4 & 29.4 \\
Post-mordanting & 56.5 & 8.0 & 28.4 & 29.5 & 74.4 & 37.1 \\
Pashmina fabric & & & & & & \\
Without mordant & 55.7 & 4.3 & 25.5 & 25.9 & 80.3 & 26.9 \\
Pre-mordanting & 52.6 & 4.3 & 28.2 & 28.5 & 81.2 & 30.7 \\
Simultaneous mordanting & 55.2 & 3.9 & 25.8 & 26.1 & 81.4 & 27.4 \\
Post-mordanting & 37.2 & 5.2 & 18.9 & 19.6 & 74.5 & 43.8 \\
\hline
\end{tabular}

vacuum evaporator, and the material was reduced to one fourth of its original volume to obtain the final dyeing extract.

\section{Scouring of fabrics}

All the test fabrics (wool, cotton, silk and pashmina) were cut into $5 \times 6 \mathrm{~cm}$ and were washed for $20 \mathrm{~min}$ with $2 \%$ non-ionic soap (Labolene) at $50{ }^{\circ} \mathrm{C}$ by keeping the material-to-liquor ratio at 1:50 for silk and pashmina and 1:80 for cotton and wool fabrics. The material was then washed thoroughly with plenty of tap water and was soaked in distilled water for $30 \mathrm{~min}$ prior to dyeing (Plate 2).

\section{Dyeing of fabrics}

The process of the dyeing was carried out in a water bath by maintaining the material-to-liquor ratio of 1:60 for wool and pashmina fabrics, 1:40 for cotton fabric and 1:60 for silk fabric, respectively. The dyeing of wool, silk and pashmina fabrics was performed at acidic $\mathrm{pH}$ by adding required amount of acetic acid $\left(\mathrm{CH}_{3} \mathrm{COOH}\right)$, whereas cotton fabric was dyed at basic $\mathrm{pH}$ by adding sodium carbonate $\left(\mathrm{Na}_{2} \mathrm{CO}_{3}\right)$, which acts as an electrolyte for cellulosic fibres, containing higher bonds than 
Table 3 Fastness grades of dyed fabrics dyed with Quercus robur L. (fruit cups) and Salix alba L. (wood ash) adopting different mordanting methods

\begin{tabular}{|c|c|c|c|c|c|c|c|}
\hline \multirow[t]{3}{*}{ Method } & \multirow{2}{*}{\multicolumn{2}{|c|}{$\begin{array}{l}\text { Washing } \\
\text { fastness }\end{array}$}} & \multirow{3}{*}{$\begin{array}{l}\text { Light } \\
\text { fastness } \\
\text { CC }\end{array}$} & \multicolumn{4}{|c|}{ Rubbing fastness } \\
\hline & & & & \multicolumn{2}{|c|}{ Staining } & \multicolumn{2}{|c|}{ Fading } \\
\hline & $\mathrm{CC}$ & CS & & Dry & Wet & Dry & Wet \\
\hline \multicolumn{8}{|l|}{ Wool fabric } \\
\hline Without mordant & 4 & $4 / 5$ & $4 / 5$ & $4 / 5$ & $4 / 5$ & 5 & $4 / 5$ \\
\hline Pre-mordanting & $4 / 5$ & 5 & $4 / 5$ & 5 & 5 & 5 & 5 \\
\hline Simultaneous mordanting & 4 & 5 & $4 / 5$ & 5 & $4 / 5$ & 5 & $4 / 5$ \\
\hline Post-mordanting & 4 & 5 & $4 / 5$ & 5 & 5 & 5 & 5 \\
\hline \multicolumn{8}{|l|}{ Silk fabric } \\
\hline Without mordant & $4 / 5$ & $4 / 5$ & $4 / 5$ & 5 & 5 & 5 & 5 \\
\hline Pre-mordanting & $4 / 5$ & 5 & $4 / 5$ & 5 & 5 & 5 & $4 / 5$ \\
\hline Simultaneous mordanting & 5 & 5 & $4 / 5$ & 5 & 5 & 5 & $4 / 5$ \\
\hline Post-mordanting & 5 & 5 & $4 / 5$ & 5 & 5 & 5 & 5 \\
\hline \multicolumn{8}{|l|}{ Cotton fabric } \\
\hline Without mordant & $4 / 5$ & $4 / 5$ & 4 & 5 & 5 & 5 & $4 / 5$ \\
\hline Pre-mordanting & $4 / 5$ & 5 & $4 / 5$ & 5 & 5 & 5 & 5 \\
\hline Simultaneous mordanting & 4 & 5 & 4 & 5 & 5 & 5 & $4 / 5$ \\
\hline Post-mordanting & 4 & 5 & $4 / 5$ & 5 & 5 & 5 & 5 \\
\hline \multicolumn{8}{|l|}{ Pashmina fabric } \\
\hline Without mordant & $4 / 5$ & 5 & $4 / 5$ & $4 / 5$ & 4 & 5 & 5 \\
\hline Pre-mordanting & 5 & 5 & $4 / 5$ & $4 / 5$ & 4 & 5 & 5 \\
\hline Simultaneous mordanting & 4 & 5 & 4 & 5 & 5 & 5 & $4 / 5$ \\
\hline Post-mordanting & $4 / 5$ & 5 & $4 / 5$ & 5 & 5 & 5 & 5 \\
\hline
\end{tabular}

CC colour change, CS colour staining

protein fibres. All the test fabrics were dipped in $100 \mathrm{ml}$ of dyeing solution of $4 \%$ dye (OWM) at room temperature. The material was then removed and washed with $1 \%$ of detergent and water 2-3 times followed by squeezing and drying operations at room temperature.

\section{Mordanting}

The process of mordanting was carried out by adopting pre-, simultaneous and post-mordanting methods using $4 \%$ of mordant solution and maintaining 1:50 materialto-liquor ratio. The process of mordanting was carried at $60-75^{\circ} \mathrm{C}$ with gentle stirring and continued for $1 \mathrm{~h}$.

\section{Percent absorption determination}

Amount of the dye absorption by the selected textile fabrics was evaluated by recording the optical density ( $\max$ ) of the dyeing solution both before and after dyeing process using a ultraviolet-visible adsorption spectra (UV-VIS) PCbased double beam spectrophotometer (Systronics 2202). The OD at $\chi \max$ was recorded over the range of 200
$800 \mathrm{~nm}$. The final value of the percent absorption was calculated by using the following equation.

$$
\text { Percent absorption }=\frac{\text { O. } \mathrm{D} \text { before dyeing-O. } \mathrm{D} \text { after dyeing }}{\text { O. } \mathrm{D} \text { before dyeing }} \times 100
$$

\section{Evaluation of CIE colour coordinates $\left(L^{*} a^{*} b^{*} C^{*} h^{\circ}\right.$ and $\left.\Delta E\right)$}

The colour coordinates of the dyed and undyed fabrics were determined by chromometer (Model CR-2000, Minolta, Osaka, Japan) equipped with 8-mm measuring head and AC illumination (6774 K) based on CIE system (International Commission on Illumination). Manufacturer's standard white plate was used for calibration of the instrument. $L^{*}, a^{*}$ and $b^{*}$ coordinates were recorded by the measuring instrument directly, whereas values of Chroma $\left(C^{*}\right)$, hue angle $\left(h^{\circ}\right)$ and total colour change $(\Delta E)$ were calculated by below mentioned equations.

$$
\begin{gathered}
\text { Chroma } \left.=\left(a^{* 2}+b^{* 2}\right)^{1 / 2}\right) \\
\text { Hue }(h)=\tan ^{-1} b * / a *
\end{gathered}
$$

The value of the total colour change was calculated from $L^{*}, a^{*}$ and $b^{*}$ values using the following equation.

Total colour change $(\Delta E)$ :

$$
(\Delta E)=\left[(\Delta L *)^{2}+(\Delta a *)^{2}+(\Delta b *)^{2}\right]^{1 / 2}
$$

where

$\Delta L^{*}=L^{*}$ sample $-L^{*}$ standard

$\Delta a^{*}=a^{*}$ sample $-a^{*}$ standard

$\Delta b^{*}=b^{*}$ sample $-b^{*}$ standard

\section{Determination of colour strength $(K / S)$}

The value of the colour strength $(K / S)$ of the fabrics was recorded using a JAYPAK-4802 colour matching system (Jay Instruments Ltd., Mumbai, India) at D65 illuminate/10 Deg observer. The reflectance of the samples was measured at $360-760 \mathrm{~nm}$. The $K / S$ value in the visible region of the spectrum $(400-700 \mathrm{~nm})$ was calculated based on the Kubelka-Munk equation mentioned below

$$
\frac{K}{S}=\frac{(1-R \lambda) 2}{2 \times R \lambda}
$$

where $K$ is the coefficient of absorption, $S$ is the scattering coefficient and $R$ is the surface reflectance value of the sample at a particular wavelength, where maximum absorption occurs for a particular dye/colour component.

\section{Relative colour strength}

The relative colour strength $(K / S$ value at maximum wavelength) was calculated by adopting the following equation. 


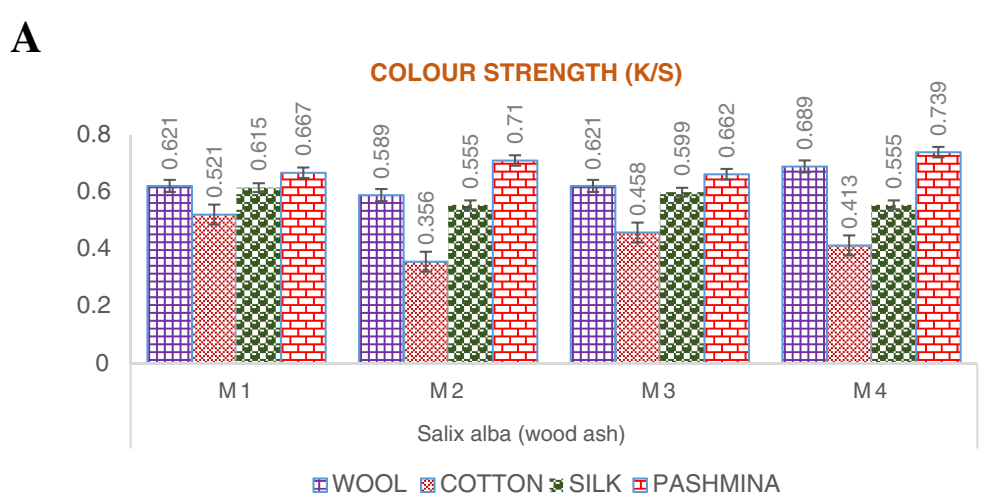

M1: Without Mordant, M2: Pre Mordanting, M3: Simultaneous Mordanting, M4: Post Mordanting

B

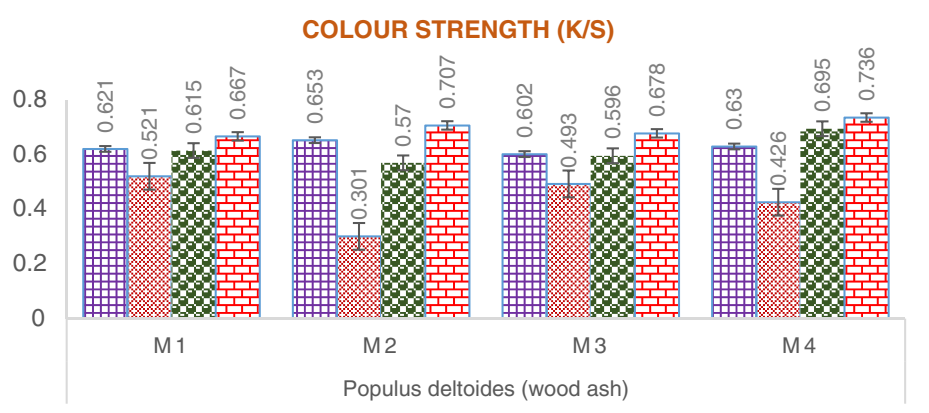

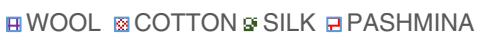

M1: Without Mordant, M2: Pre Mordanting, M3: Simultaneous Mordanting, M4: Post Mordanting

Fig. 2 a Colour strength (K/S) of the dyed fabrics using Salix alba L. (wood ash). M1: without mordant, M2: pre-mordanting, M3: simultaneous mordanting, M4: post-mordanting. b Colour strength (K/S) of the dyed fabrics using Populus deltoides Bartram Ex Marsh. M1: without mordant, M2: pre-mordanting, M3: simultaneous mordanting, M4: post-mordanting

Relative colour strength $=\frac{(K / S) \text { extracted }}{(K / S) \text { raw }}$

\section{Determination of colour fastness properties}

The retention of the dye by the fabrics were evaluated by different colour fastness tests as per ISO 105-B02 for light, ISO $105 \mathrm{X}-12$ for rubbing and ISO 105-C01 for washing, respectively. Grades for the colour change and colour staining were assigned as per ISO 105-AO2 and ISO 105-A03 in conformity with the evaluators.

\section{Results and discussion}

\section{Dye exhaustion}

The percent absorption of the dye by the different fabrics varied significantly, where both mordanted and unmordanted fabrics showed an efficient dye uptake by adopting different mordanting methods. Satisfactory results were also recorded in unmordanted samples; however, percent absorption of the mordanted fabrics recorded higher and efficient values with both Salix alba (wood ash) and Populus deltoides (wood ash) (Fig. 1a, b). The highest value of the percent absorption was recorded with Populus deltoides (wood ash) mordant by the pashmina fabric adopting premordanting method (Fig. 1b). Pashmina fabric recorded the highest absorption results, including and excluding the mordants than all the other test fabrics. These results may be due to the presence of multifunctional groups in the protein polymer $\left(-\mathrm{NH}_{2},-\mathrm{OH},-\mathrm{COOH}\right)$ in the pashmina fabric which provides a bridge between the dye and the fabric, resulting efficient absorption than the other fabrics (Temani et al. 2011). The lowest values of the percent absorption was recorded by cotton fabric adopting pre-mordanting method using both Salix alba L. and Populus deltoides (wood ash) (Fig. 1a, b). The cotton fabric does not show satisfactory results as compared to other test fabrics. Cotton fabric with least absorption values recorded highest value with Salix alba (wood ash) adopting pre-mordanting method, which may be due to weak coordination complexes formed between cellulosic polymer and dye molecules (Fig. 1a). This low coordination tendency of cotton with the dyes and mordants may have resulted in low dye absorption. Tiwari et al. (2010) also reported lesser dye ability of cotton than that of the wool. In wool fabric, highest 
A

RELATIVE COLOUR STRENGHT (K/S)

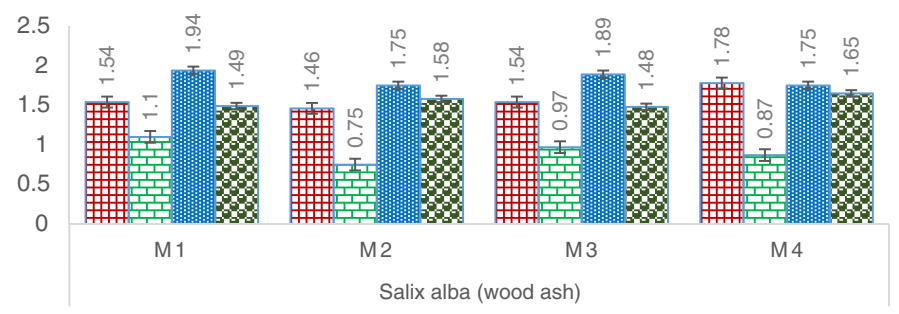

田WOOL ㅁOTTON 四SILK GPASHMINA

M1: Without Mordant, M2: Pre Mordanting, M3: Simultaneous Mordanting, M4: Post Mordanting

B

RELATIVE COLOUR STRENGHT (K/S)

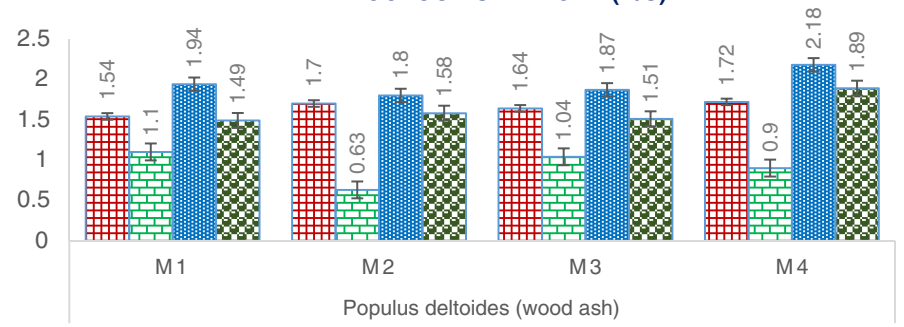

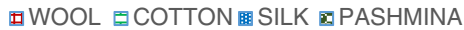

M1: Without Mordant, M2: Pre Mordanting, M3: Simultaneous Mordanting, M4: Post Mordanting

Fig. 3 a Relative colour strength (K/S) of the dyed fabrics in Salix alba L. (wood ash). M1: without mordant, M2: pre-mordanting, M3: simultaneous mordanting, M4: post-mordanting. b Relative colour strength (K/S) of the dyed fabrics in Populus deltoides Bartram Ex Marsh. M1: without mordant, M2: pre-mordanting, M3: simultaneous mordanting, M4: post-mordanting

value of absorption was recorded with Populus deltoides (wood ash) adopting pre-mordanting method. The efficient absorption of the wool fabric is due to its fibre containing equal amount of amino and carboxyl groups which ionize and form zwitter ion. At low $\mathrm{pH}$, the hydrogen ions are absorbed by carboxyl groups present in wool. At high $\mathrm{pH}$, the protein looses hydrogen ions leaving behind ionized groups. Thus, wool and pashmina can absorb maximum dye in acidic medium (Mathur and Bhandari 2001). Silk fabric recorded the highest value with Populus deltoides adopting simultaneous mordanting; and mordanted samples showed better percent dye absorption than the unmordanted samples, thus confirming the best absorption results of the natural dyes when used in combination with natural mordants (Fig. 1b). The variation in absorption by the different fabrics with each mordant, adopting different methods, may be due to the formation of the chemical bridge through the mordant that enhances the binding capacity of dye molecules to the fabric thus also prevents the bleeding and fading of colour (Prabhu and Bhute 2012).

\section{Colour values of dyed fabrics}

The colour coordinates of the fabrics dyed with Salix alba varied significantly. The cotton fabric attained the luminous white colour with less colour quality by simultaneous mordanting method. Whereas, wool, pashmina and silk fabrics recorded the lowest values of lightness indicating the intense colour quality of the fabrics with different shades and tones (Plate 3). The lowest value of the lightness was recorded by pashmina fabric in post-mordanting method followed by silk and wool in simultaneous and post-mordanting, respectively (Table 1). In case of the fabrics dyed with Populus deltoids, the highest $\mathrm{L}^{*}$ was recorded in cotton fabric showing luminous white colour in post-mordanting method. However, wool, silk and pashmina fabrics showed bright colour quality in without mordant, pre-mordanted and without mordant, respectively (Table 2 ). The positive $a^{*}$ values of all the dyed fabrics represented the light to bright reddish tones of the fabrics. While, the positive $b^{*}$ values of all the dyed fabrics represented the light to bright yellowish tones of the dyed fabrics. The hue of the fabrics showed reddish, brownish and light to dark reddish brown colour in the case of the pashmina, wool and silk fabrics, respectively, with varied tones and shades of the colours. However, cotton fabric showed light and dull reddish and yellowish shades only. The difference in the values of the colour coordinates justifies the variation in the colour quality of the fabrics which changed with each mordant by adopting different mordanting methods as also depicted by the 
Table 4 Fastness grades of dyed fabrics dyed with Quercus robur L. (fruit cups) and Populus deltoides Bartram ex Marsh (wood ash) adopting different mordanting methods

\begin{tabular}{|c|c|c|c|c|c|c|c|}
\hline \multirow[t]{3}{*}{ Method } & \multirow{2}{*}{\multicolumn{2}{|c|}{$\begin{array}{l}\text { Washing } \\
\text { fastness }\end{array}$}} & \multirow{3}{*}{$\begin{array}{l}\text { Light } \\
\text { fastness } \\
\text { CC }\end{array}$} & \multicolumn{4}{|c|}{ Rubbing fastness } \\
\hline & & & & \multicolumn{2}{|c|}{ Staining } & \multicolumn{2}{|c|}{ Fading } \\
\hline & $\mathrm{CC}$ & CS & & $\overline{\text { Dry }}$ & $\overline{\text { Wet }}$ & Dry & Wet \\
\hline \multicolumn{8}{|l|}{ Wool fabric } \\
\hline Without mordant & 4 & $4 / 5$ & $4 / 5$ & $4 / 5$ & $4 / 5$ & 5 & $4 / 5$ \\
\hline Pre-mordanting & 4 & 5 & 5 & 5 & 5 & 5 & 5 \\
\hline Simultaneous mordanting & 3 & 5 & 5 & 5 & 5 & 5 & 5 \\
\hline Post-mordanting & 4 & 5 & $4 / 5$ & 5 & 5 & 5 & 5 \\
\hline \multicolumn{8}{|l|}{ Silk fabric } \\
\hline Without mordant & $4 / 5$ & $4 / 5$ & $4 / 5$ & 5 & 5 & 5 & 5 \\
\hline Pre-mordanting & $3 / 4$ & 5 & $4 / 5$ & 5 & 5 & 5 & 5 \\
\hline Simultaneous mordanting & $4 / 5$ & 5 & 4 & 5 & 5 & 5 & 5 \\
\hline Post-mordanting & 5 & 5 & $4 / 5$ & 5 & 5 & 5 & 5 \\
\hline \multicolumn{8}{|l|}{ Cotton fabric } \\
\hline Without mordant & $4 / 5$ & $4 / 5$ & 4 & 5 & 5 & 5 & $4 / 5$ \\
\hline Pre-mordanting & $3 / 4$ & 5 & $4 / 5$ & 5 & 5 & 5 & 5 \\
\hline Simultaneous mordanting & 4 & 5 & 4 & 5 & 5 & 5 & 5 \\
\hline Post-mordanting & $4 / 5$ & 5 & 4 & 5 & 5 & 5 & 5 \\
\hline \multicolumn{8}{|l|}{ Pashmina fabric } \\
\hline Without mordant & $4 / 5$ & 5 & $4 / 5$ & $4 / 5$ & 4 & 5 & 5 \\
\hline Pre-mordanting & $4 / 5$ & 5 & 5 & 5 & $4 / 5$ & 5 & 5 \\
\hline Simultaneous mordanting & 4 & 5 & 4 & 5 & $4 / 5$ & $4 / 5$ & 4 \\
\hline Post-mordanting & $4 / 5$ & 5 & $4 / 5$ & 5 & $4 / 5$ & 5 & 5 \\
\hline
\end{tabular}

CC colour change, CS colour staining

values of the $\Delta E$ which shows the colour change with reference to the sample without dye and mordant. The colorimetric values of both the fabrics mordanted with Salix alba and Populus deltoides (wood ash) showed significant differences with shades and colour ranging from light yellow to yellow, brown to reddish brown, light brown to brown and dark brown colours.

The pashmina, wool and silk fabrics showed dark colours with fast brightness. However, pashmina fabric showed brighter shades and dark colours followed by wool and silk fabrics. The cotton fabric does not show effective shades and tones. The usage of the two mordants with a single dye showed different shades and tones and represented different colour shades (Tables 2 and 3). These changes could be attributed to resonating structures of dyes with different mordants (Montazer and Parvinzadeh 2004). Chroma of all the dyed fabrics except cotton recorded higher values, representing the brighter colours of dyed fabrics (Almela et al. 1995). The prominent variation among the dyed samples could be correlated with

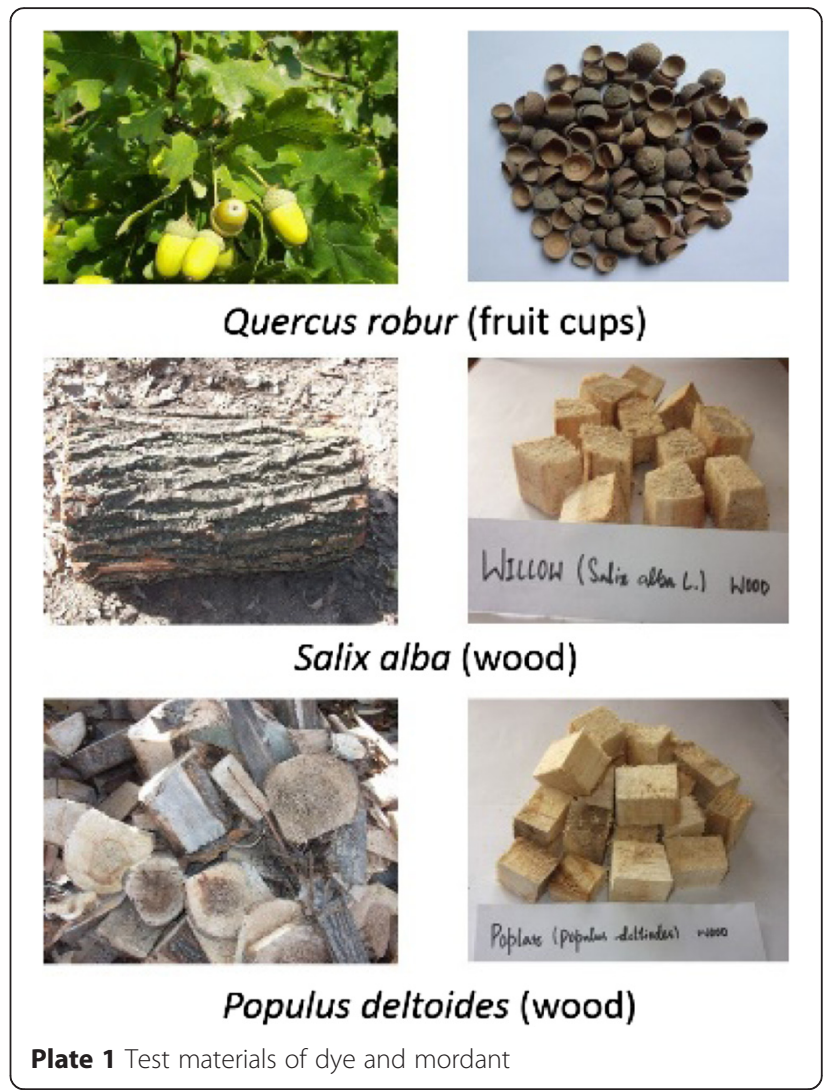

complex coordination of mordant ions with dye molecules on the fabric, which enhances the uptake of colourant during dyeing; however, in mordanting, some of the mordant is stripped out in the dye bath, which subsequently forms an insoluble complex with

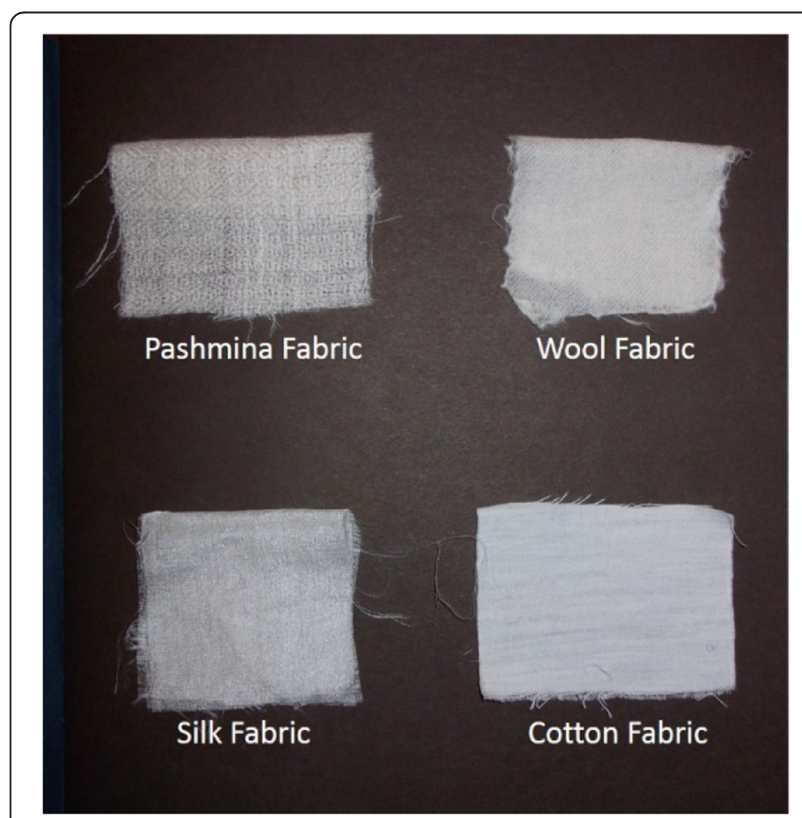

Plate 2 Test materials for dyeing 


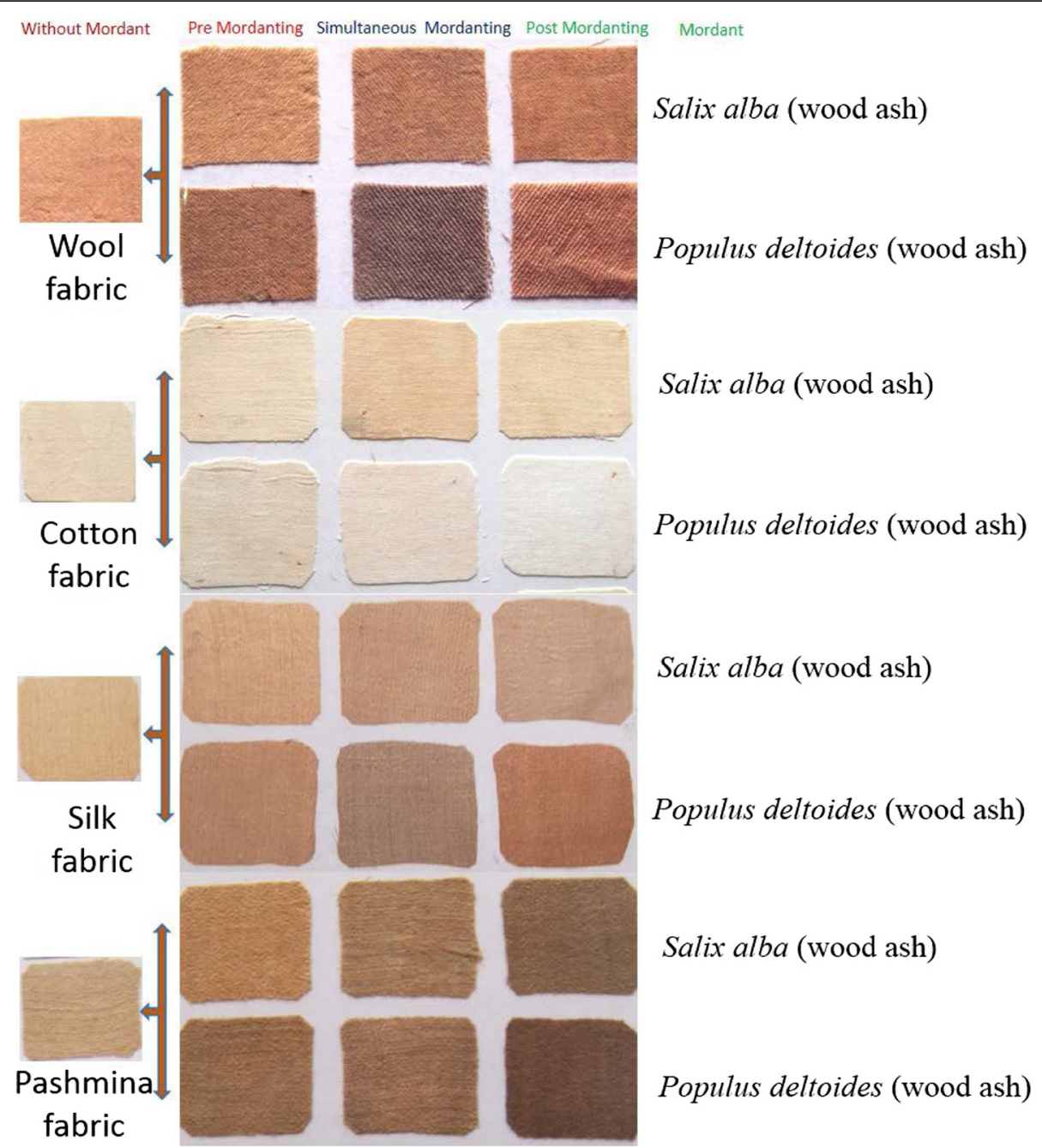

Plate 3 Dyed fabrics in combination with mordants

dye molecules in solution and results in least uptake of dye (Deo and Desai 1999).

\section{Colour strength $(K / S)$ of the dyed fabrics}

The mordant and methods of mordanting showed the significant variation in colour strength $(K / S)$ of the dyed fabrics. The dye, mordants, methods, interaction of dye $\times$ mordant, dye $\times$ method, mordant $\times$ method and dye $x$ mordant $x$ method showed a significant effect on colour strength of the dyed fabrics. Among the selected fabrics, maximum colour strength values $(K / S) 0.739$ and 0.736 were recorded in pashmina fabric using Salix alba and Populus deltoides in post-mordanting method (Fig. 1a, b), whereas, the lowest value $(0.662)$ was recorded with Salix alba in simultaneous mordanting, highest colour strength (0.689) was recorded in wool fabric with Salix alba in post-mordanting and lowest value (0.602) was recorded with Populus deltoides in simultaneous mordanting. Cotton fabric does not show much affinity for the dye, mordant and their combinations. Silk fabric exhibited the highest value of 0.695 with Populus deltoides in post-mordanting (Fig. 2b), while the lowest value (0.555) was recorded with Salix alba in pre- and postmordanting (Fig. 2a). The pashmina fabric recorded the maximum $K / S$ value followed by the wool, silk and cotton fabrics. The mordants used in combination with the dyes and in isolation showed a significant change in the colour strength of the fabrics as per the type of the fabrics and method adopted. However, unmordanted samples also showed fair $K / S$ values for each fabric and method. The relative colour strength followed the similar trend and altered as per the efficiency in the $K / S$ of the dyed fabrics in different methods (Fig. 2a, b; Fig. 3a, b). The lower values of the colour strength of the cotton fabric can be related to the unsaturated moiety of the natural dyes bearing ionizable hydroxyl and carboxylic groups. Cotton by its nature is negatively charged in water, thus exhibiting poor absorption for natural 
dyes due to the repulsion effect which causes lower colour strength of the dye on the fabric (Kampeerapappun et al. 2010).

\section{Fastness properties of the dyed fabrics}

The colour fastness is determined by the end use of the fabrics. The retention of the dye by the fabrics when exposed to different tests recorded good to excellent and excellent grades, indicating efficient retention. However, grades of the mordanted samples recorded proficient than that of the unmordanted samples (Tables 3 and 4). The retention of the dye with the Salix alba mordant showed good, good to excellent and excellent grades in case of washing and light fastness. Whereas, rubbing fastness of the dyed fabrics recorded good to excellent to excellent grades in both staining and fading in dry and wet condition. The fabrics dyed with Populus deltoides recorded fair, fair to good, good, good to excellent and excellent grades in washing test. Light fastness recorded good to excellent to excellent grades and rubbing fastness recorded good to excellent to excellent in wool, silk and cotton fabrics. However, pashmina fabric showed good, good to excellent and excellent grades. The overall retention of the dye in combination with the different mordants showed finest grades with least fading and bleeding (Tables 3 and 4). However, the unmordanted dyed samples also showed satisfactory grades with both the mordants, which could be attributed to the yarn which binds the affinity of the colouring components in the form of $\mathrm{H}$ bonding, ionic bonding, and van der Waals forces (Khan et al. 2015; Yusuf et al. 2015). The variation in grades due to different methods may be due to the mordants which chelate several dye molecules together, creating a large complex thus providing a link between the dye and the fibre (Cardon 2007). The washing fastness of the dye is greatly influenced by the rate of the diffusion of the dye and the state of the dye inside the fibre (Jothi 2008). The changes in fastness grades in both wet and dry rub may be due to the water-soluble dye molecules which dissolve in water, making them easier to get removed from the fibre (Haji 2010).

\section{Conclusions}

The dye and mordants extracted from unexplored plant materials were found to be effective colouring agents for the dyeing of pashmina, wool and silk fabrics. The mordants enhanced the colour quality of the fabrics due to the increased efficiency in absorption, colour strength, colour coordinates and fastness grades in terms of washing, light and rubbing, respectively. However, the cotton fabric showed less affinity for the dye and mordant with lower values and grades. The most excellent results of the dye and mordant were recorded in pashmina followed by wool and silk fabrics. The dye applied on fabrics showed striking shades with the change in mordant and method both in combination and in isolation which were represented by fast and light colours of brown, red and yellow with varying shades and tones. Thus, the recorded observations recommend natural dyeing agents as a potential colouring material for wool, pashmina and silk fabric which can be explored commercially at national and international levels.

\section{Competing interests \\ The authors declare that they have no competing interests.}

\section{Authors' contributions}

SMG acted as the main scholar, conducted the whole research work under the supervision of the SA and PKM. SJAB and NAM performed the collection of the samples and helped in drafting the manuscript. All authors read and approved the final manuscript.

\section{Acknowledgements}

The author is highly thankful to University Grants Commission for awarding MANF fellowship, Department of Chemical Engineering and Technology, IIT (BHU), Facility of Pashmina Quality Evaluation Laboratory developed by Division of LPT (SKUAST-K) and Division of Environmental Sciences (SKUASTK) for providing support and laboratory facilities.

\section{Author details}

${ }^{1}$ Environmental Sciences, SKUAST-K, Shalimar, Srinagar, Jammu and Kashmir, India. ${ }^{2}$ Faculty of Forestry, SKUAST-K, Srinagar, Jammu and Kashmir, India.

${ }^{3}$ Department of Chemical Engineering and Technology, IIT (BHU), Varanasi, Varanasi, Uttar Pradesh, India.

Received: 10 January 2016 Accepted: 21 May 2016

Published online: 24 June 2016

\section{References}

Almela, L., Javaloy, S., Fernendez, L. J. A., \& Lopez, R. J. M. (1995). Comparison between the tristimulus measurements $Y x y$ and $L^{*} a^{*} b^{*}$ to evaluate the colour of young red wines. Food Chemistry, 53(3), 321-327.

Aminoddin, H. (2010). Functional dyeing of wool with natural dye extracted from Berberis vulgaris wood and Rumex hymenosepolus root as biomordant. Iranian Journal of Chemistry and Chemical Engineering, 29(3), 55-60.

Cardon, D. (2007). Natural dyes: Sources, tradition, technology and science. London: Archetype Publications. ISBN: 190498200x.

Deo, H. T., \& Desai, B. K. (1999). Dyeing of cotton and jute with tea as a natural dye. Journal of the Society of Dyers and Colourists, 115(7-8), 224-227.

Dos, S. A. B., Cervntes, F. J., \& Van, L. J. B. (2007). Review paper on current technologies for decolourisation of textile wastewaters: perspectives for anaerobic biotechnology. Bioresource Technology, 98(12), 2369-2385.

Geelani, S. M., Ara, S., Mishra, P. K., Bhat, S. J. A., Hanifa, S., Haq, S., et al. (2015a). Eco-friendly dyeing of wool and pashmina fabric using Quercus robur L. (fruit cups) dye and Salix alba L. (wood extract) mordant. Journal of Applied and Natural Science, 7(1), 138-143.

Geelani, S. M., Bhat, S. J. A., Qazi, G., Qasba, S., Qureshi, S. N., Parray, A. A., et al. (2015b). Utilization of Quercus robur L. (fruit cups) and Salix alba L. (wood extract) as dyeing agents for silk and cotton fabrics. Journal of Industrial Pollution Control, 31(2), 227-234.

Gyanendra, T., Mukesh, K. Y., Prabhat, U., \& Shardendu, M. (2015). Natural dyes with future aspects in dyeing of textiles: a research article. International Journal of Pharma Tech Research, 8(1), 096-100.

Haji, A. (2010). Functional dyeing of wool with natural dye extracted from Berberis vulgaris wood and Rumex hymenosepolus root as biomordant. Iranian Journal Chemistry and Chemical Engineering, 29(3), 55-59.

Jothi, D. (2008). Extraction of natural dyes from African marigold flower (Tagetes erecta $\mathrm{L}$ ) for textile coloration. Autex Research Journal, 8(2), 49-53.

Kampeerapappun, P., Phattararittigul, T., Jittrong, S., \& Kullachod, D. (2010). Effect of chitosan and mordants ion dyeability of cotton fabrics with Ruellia tuberosa Linn. Chiang Mai Journal of Science., 38(1), 95-104. 
Khan, S. A., Islam, S., Shahid, M., Khan, M. I., Yusuf, M., Rather, L. J., et al. (2015). Mixed metal mordant dyeing of wool using root extract of Rheum emodi (Indian Rhubarb/Dolu). Journal of Natural Fibers, 12(3), 243-255.

Kulkari, S. S., Bodake, U. M., \& Pathode, G. R. (2011). Extraction of natural dye from chili (Capsicum annum) for textile colouration. Universal Journal of Environmental Research and Technology, 1(1), 58-63.

Kumaresan, M., Palanisamy, P. N., \& Kumar, P. E. (2011). Application of eco-friendly natural dye obtained from flower of Spathodea Campanulata on silk using combination of mordants. European Journal of Scientific Research, 52(3), 306-312.

Lodrick, M. W., Kidist, T., \& Senelisile, M. (2015). Mango bark mordant for dyeing cotton with natural dye: fully eco-friendly natural dyeing. International Journal of Textile Science., 4(2), 36-41.

Mathur, J. P., \& Bhandari, C. S. (2001). Use of beet sugar as wool colourant. Indian Journal of Fibre and Textile Research, 26(3), 313-316.

Montazer, M., \& Parvinzadeh, M. (2004). Colourimetric properties of wool dyed with natural dyes after treatment with ammonia. Colouration Technology., 120(4), 161-166.

Ogugbue, C J \& Sawidis, T. (2011). Bioremediation and detoxification of synthetic wastewater containing triaryl methane dyes by Aeromonas hydrophila isolated from industrial effluent. Biotechnology Research International. doi: 10. 4061/2011/967925.

Prabhu, K. H., \& Bhute, A. S. (2012). Plant based natural dyes and mordants: a review. Journal of Natural Product and Plant Resources, 2(6), 649-664.

Rajendran, R., \& Thamarai, S. B. (2014). Natural dyeing of cotton fabrics with pigment extracted from Roseomonas Fauriae. Universal Journal of Environmental Research and Technology, 4(1), 54-59.

Rungruangkitkrai, N., \& Mongkholrattanasit, R. (2012). Eco friendly of textiles dyeing and printing with natural dyes (pp. 1-17). Bangkok: RMVTP International conference: Textiles and Fashion.

Sachan, K., \& Kapoor, V. P. (2007). Optimization of extraction and dyeing conditions for traditional turmeric dye. Indian Journal of Traditional Knowledge, 6(2), 270-278.

Singh, R., \& Srivastava, S. (2015). Exploration of flower based natural dyes-a review. Research Journal of Recent Sciences, 4, 6-8.

Temani, P., Shakyawar, D. B., Ammayappan, L., Goyal, V., \& Wani, S. A. (2011). Standardization of dyeing condition of cochineal extract on pashmina yarn. Journal of the Textile Association, 72(2), 90-92.

Tiwari, H. C., Singh, P., Mishra, P. K., \& Srivastava, P. (2010). Evaluation of various techniques for extraction of natural colourants from pomegranate rind - ultrasound and enzyme assisted extraction. Indian Journal of Fibre and Textile Research, 35(3), 272-276.

Wanyama, P. A. G., Kiremire, B. T., \& Murumu, J. E. S. (2014). Extraction, characterization and application of natural dyes from selected plants in Uganda for dyeing of cotton fabrics. African Journal of Plant Sciences, 8(4), 185-195.

Yusuf, M., Shahid, M., Khan, M. I., Khan, S. A., Khan, M. A., \& Mohammad, F. (2015). Dyeing studies with henna and madder: a research on effect of tin (II) chloride mordant. Journal of Saudi Chemical Society, 19(1), 64-72.

\section{Submit your manuscript to a SpringerOpen ${ }^{\circ}$ journal and benefit from:}

- Convenient online submission

- Rigorous peer review

- Immediate publication on acceptance

- Open access: articles freely available online

- High visibility within the field

Retaining the copyright to your article 